\title{
新会長として
}

筒井晃 一

平成 15 年度通常総会で, 故甘利会長の後を受けて伝統と歴史のある色材協会の新会長に就 任を致しました。昨年度は本部副会長としての重責を十分に果たさないまま今回, 会長の大役 を仰せつかり，戸惑うと同時に協会の一層の発展に尽くさねばという思いで決意を新たにして おります。何分微力な私ですので, 副会長, 役員の皆様と一緒に, またそのお力をお借りして 協会の課題に取り組み，新たなる協会発展に尽くしたいと考えております。会員の皆様のさら なるご支援とご協力を打願い申し上げます。

さて現在の協会を取り巻く環境は厳しく，また流動的な要素がたくさんあります。たとえば マイナス要素としては，国内経済のデフレ進行により，平成 15 年度の経済産業省予算は前年

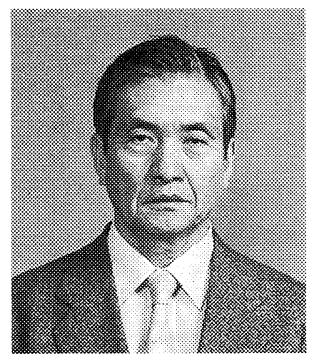
度以下に抑制され, また平成 14 年の塗料, 印刷インキ, 化粧品の生産量は前年比, $1 \sim 2 \%$ 減と協会活動への参加 マインドを圧迫していること, また情報技術の普及は, いつどこでも誰もが「欲しい情報」を入手できるため, 協会 活動の「質」が問われはじめていることであります。

一方プラス要素では, 国が技術革新による経済再生を目指し, 昨年 12 月に報告された「産業発掘戦略」では 4 技 術革新分野として「情報家電・ブロードバンド・IT」，「健康・バイオテクノロジー」，「環境・エネルギー」，「ナノ テクノロジー・材料」を特定し，経済産業省予算も対前年で，各 190，50，130，100 億円の増額投資となったことで す。色材技術はこれら 4 技術分野を網羅するものですから, 既存色材分野でのさらなる技術革新に加えて, これら技 術分野で必要とされる色材技術開発に対しても協会の果たすべき役割が多くあります。

これらマイナス要素は協会変革のチャンスととらえ, またプラス要素は積極的に活用することで, 協会の発展, さ らには関係分野の発展に貢献できるものと確信しております。従いましてこれを実行するにあたり, 次の方針で協会 活動を運営していきたいと思っております。

方針 1 は,「会員サービスの徹底化」です。色材協会の活動は, 色材分野での(1)研究・技術の啓蒙, 情報交換, に 加えて(2)産官学の連携による, 先端技術開発, 専門と実務教育の融合, さらには(3)グローバル化に向けた技術開発 と，幅広く「会員サービス」を提供することであります。平成 15 年度ではこの「会員サービス」を“時代にあった” 形で質的に改革することで, 会員の皆様に満足していただけるサービスを提供したいと考えております。これは(1)関 東, 関西, 中部支部が独自に，また連携して，既存分野はもちろん 4 技術分野をも盛り込み，“行事に参加したくな る”企画で協会活動の拡大を進め，(2)「ホームページ委員会」では，発信情報の充実化，会員からの提言などのホー ムページ改革を継続し, (3)「編集委員会」では本年度を“会誌変革”の実行の年とし，また論文特集号の発刊，新た な活動としての電子ジャーナル化への取り組み, などにより具体的に進めてまいります。

方針 2 は「財政改革の断行」です。これら協会変革の実行には財源の確保が必須であります。この財源を確保する には前年度に発足した「財政改革委員会」のアクション・プログラムを実行していくことであります。これは(1)協会 活動の基盤としての維持会員, 正会員, 学生会員数を増やすこと, (2) “時代が求める”企画で協会事業収入を計るこ と, (3)協会本部，支部の支出の抑制と収入の有効活用をすることであります。このような財政改革を進めることで， 会員の皆様が満足されるサービスの提供が可能となります。

協会では 5 月に「分散入門講座」「環境を考えた塗料の最新技術動向」を開催しますが，さらに新しい工夫を凝ら して, 各種講座, 講演会, 夏季ゼミナールなどの企画を進め, 協会活動の拡大に結びつけてまいります。また 7 月 3 日，4 日の色材研究発表会では一般研究発表に加えて「環境と色材」「ナノテクノロジーと色材」の特別セッション を設けるなど “時代が求める”企画も進めております。会員および関係者の皆様のこれら行事へのご参加, またご発 表を心よりお待ちしております。

これら 2 つの方針をもとに, 副会長, 役員の皆様と一致協力しながら色材協会のさらなる発展を目指して尽力して いく所存でありますが，重ねて会員および関係者皆様のご支援とご協力をお願い申し上げます。 


\title{
Original Paper
}

J. Jpn. Sco. Colour Mater. (SHIKIZAI), 76[4], 132-137 (2003)

\section{Improvement of Drying Rate for Urushi (Oriental Lacquer) and Artificial Urushi by Utilizing Protein Hydrolyzate}

\author{
Hiroshi $\mathrm{O}_{\mathrm{Yabu}}{ }^{*}$, Toru $\mathrm{A}_{\mathrm{Sami}}{ }^{*}$, Nobuyuki $\mathrm{A}_{\mathrm{NDO}}{ }^{*}$, Osamu $\mathrm{Y}_{\mathrm{Amamoto}}{ }^{* *}$ and Toshio $\mathrm{O}_{\mathrm{GaWA}}{ }^{* * *}$
}

\begin{abstract}
We used protein hydrolyzate, which was obtained from hydrolyzing albuminoid by enzyme, to improve drying rate for urushi (oriental lacquer) and artificial urushi.

Suke-urushi (transparent urushi) which is a kind of the most popular urushi, was prepared by adding the protein hydrolyzate to ki-urush (raw urushi) in order to estimate drying properties of urushi at low temperature under low humidity. This suke-urushi dried at $10^{\circ} \mathrm{C} / 50 \% \mathrm{RH}$, which meant the drying rate of urushi was improved greatly.

Meanwhile, to develop the paint by enzyme reaction using urushi as a model, that is an artificial urushi, we studied the action of enzyme laccase on synthetic urushiol analog by using the protein hydrolyzate as the third component. The enzyme is produced from culture medium of Pycnoporus Coccineus (Pycnoporus Coccineus laccase; p-laccase), which is a wood destroying fungi, and we synthesized $4-\left\{9^{\prime}(z), 12^{\prime}(z)\right.$-Octadecadienyl $\}$ catechol as an urushiol analog. This artificial urushi dried even under low humidity of $50 \% \mathrm{RH}$ at $20^{\circ} \mathrm{C}$.

Further, both the films of the suke-urushi containing the protein hydrolyzate and the artificial urushi gave broad $\tan \delta$ curve and the high temperature of $\tan \delta_{\max }$ in dynamic viscoelasticity, just like conventional urushi.

From above results, it forwarded greatly the promotion of utilizing urushi and the practical use of environmental -friendly paint such as urushi model.
\end{abstract}

Key-words: Urushi (Oriental lacquer), Artificial urushi, Drying rate, Low humidity, Protein hydrolyzate

\section{Introduction}

One of typical traditional industries in Japan is urushi work which originally began in the Jomon Period. Urushi sap is extracted from the urushi tree, Rhus verniciflua, as a raw material. This is a water-in-oil type emulsion consisting of urushiol $(60 \sim 70 \%$, Fig.1), water $(20 \sim 35 \%)$, water-soluble polysaccharides ( $5 \sim 10 \%)$, glycoprotein $(1 \sim 2 \%)$, and a slight amount of enzyme called laccase. It is usually filtrated to remove contamination. The filtrate is called ki-urushi (raw urushi). Ki-urushi is processed, which means water content is reduced to about $3 \sim 5 \%$. This proces-

Received September 5, 2002

* Kyoto Municipal Institute of Industrial Research, 17 Chudojiminami-cho, Shimogyo-ku, Kyoto-shi, Kyoto, 600-8813, Japan

** Yamamoto Kagaku Seihin-syo, Inc., 3-9-14 Tagawa, Yodogawa-ku, Osaka-shi, Osaka, 532-0027, Japan

*** Kanazawa Institute Technology, 7-1, Ohgigaoka, Nonoichi-cho, Ishikawa, 921-8821, Japan
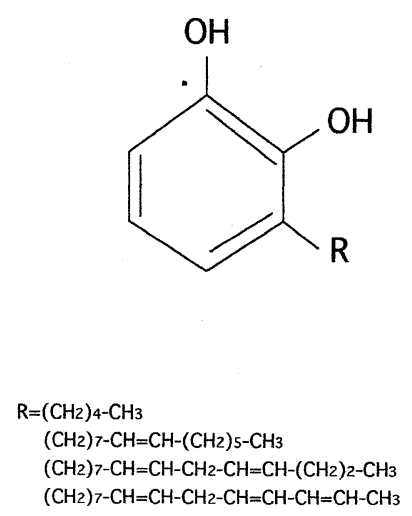

Fig. 1 Chemical structure of urushiol

sed sap is called suke-urushi (transparent urushi). Urushi has been highly estimated as natural resin paint for its characteristic and unique properties that cannot be seen in synthetic resin. At present there are many cases where synthetic resin paint needs baking to dry and it contains organic solvent. In this manner heat energy is consumed and organic solvents cause atmospheric contamination by vaporization and diffusion 
into air. Urushi is organic solvent free and its film forms high cross-linking structure at room temperature. But the current production of urushi sap is ca. $2 \sim 3$ tons per year and consumption of urushi in Japan is very small. Urushi is environmental-friendly paint, so it is expected to be more widely used. For expansion of application fields of urushi, it is an obstacle that urushi can dry only under narrow environmental condition (temperature and relative humidity).

The hardening processes have been studied in detail by Kumanotani ${ }^{1)}$ and Kenjo ${ }^{2)}$. By the catalysis of laccase and the oxidative polymerization of urushiol side chain, urushi is dried at room-temperature under high humidity and forms films which have high cross-linking density. The optimum atmospheric conditions for drying urushi are temperature of about $15 \sim 25^{\circ} \mathrm{C}$ and relative humidity of about $70 \sim 85 \%$. To keep such good conditions, urushi coated handicrafts or wooden cups are dried in a drying chamber called "muro". So the use of urushi may be limited by this specific condition. For example, urushi has been used for the architectural paint for shinto shrine and Buddhist temple from ancient times. In such cases, of course it is unable to use drying chamber because that is an open-air coating. Consequently it is unable to coat in winter season because of low temperature and low humidity. In other season, when it is low humidity, urushi does not dry or even if it dries, it takes much time to dry up. Further the physical properties of film are not favorable. If urushi would dry under lower temperature and relative humidity, the amount of urushi consumption would increase significantly.

We have been trying to improve drying rate of urushi. For example, we developed a new processing of urushi by three-roll mill ${ }^{3)}$. And we tried to add an enzyme ( $p$ -laccase) produced from a cultured medium of Pycnoporus Coccineus, which is a wood-destroying fungi, to slowdrying urushi in order to accelerate its drying rate ${ }^{4)}$. Both the processing of urushi by three-roll mill and the addition of $p$-laccase shortened drying time under optimum conditions. But these methods did not improve the drying rate at low temperature under low humidity.

On the other hand, we have been studying an artificial urushi by adopting the enzyme reaction observed in drying process of urushi. It is considered that the artificial urushi is noted as an environmental-friendly coating material. We synthesized a substance similar to urushiol, the main component of urushi sap, and after adding of $p$-laccase to it, the water in oil emulsion was formed by adding starch-urea phosphate. This is an entirely new coating material ${ }^{5,6}$. But its hardening reaction mechanism is the same as urushi, this coating material requires high humidity for drying. This artificial urushi must be hardened at low humidity for practical use.

There are some reports about reactions between urushiol and protein. Adachi et al. pointed out the change of composition in glycoprotein before and after processing of urushi, and suggested the reaction of urushiol with glycoprotein ${ }^{7)}$. Aso et al. investigated the reaction product of catechol and aniline with laccase, and confirmed that the product was dianilino-quinone ${ }^{8)}$. These results suggest that the reaction occurrs between catechol oxydate (quinone) and amino group of aniline. Moreover, it is well known that urushi causes dermatitis when it comes into contact with the skin. It has been proved that this is the reaction between urushiol and protein of the skin ${ }^{9,10,11)}$. These facts have suggested us that protein or protein derivatives would improve the curing of urushi even at low temperature under low humidity.

When natural protein such as albumin or gelatine was added into natural urushi or artificial urushi, both urushis immediately became too thick. However, the hydrolyzate of a protein, of which the molecular weight was smaller than that of the original one, did not significantly influence the viscosity. In this study, we used the hydrolyzate of a protein which was obtained by hydrolyzing albuminoid with enzyme.

From the above, we studied the way for improvement of drying rate of urushi and artificial urushi even under severe condition by utilizing protein hydrolyzate to expand application field for urushi and to forward practical use for artificial urushi. An artificial urushi containing protein or protein derivatives has been formulated and evaluated whether it is able to cure under lower temperature and lower humidity.

\section{Experimental}

\subsection{Materials}

2.1.1 Protein hydrolyzate

Protein hydrolyzate, which was obtained by hydrolyzing albuminoid with enzyme, was used. The molecular weight and main component amino acids of it are shown in Table 1.

2.1.2 Active laccase

$P$-laccase was produced by the same method as reported by Oda et $\mathrm{al}^{12)}$. The enzyme solution was purified continuously to obtain an activity of enzyme of 790,000 unit per $\mathrm{ml}$.

2.1.3 Urushiol analog

Urushiol analog, 4-\{9' $(z), 12^{\prime}(z)$ - octadecadienyl $\}$ catechol (Fig. 2), was synthesized from linoleic acid and veratrol by the method described by Terada ${ }^{13)}$. 
Table 1 Properties of protein hydrolyzate

\begin{tabular}{|c|c|c|}
\hline Origin & \multicolumn{2}{|c|}{ Albuminoid } \\
\hline $\mathrm{pH}(\mathrm{JIS}-\mathrm{K}-6503)$ & \multicolumn{2}{|c|}{$5.0 \sim 6.5$} \\
\hline Viscosity (JIS-K-6503) & \multicolumn{2}{|c|}{$8 \sim 16 \mathrm{mps}$} \\
\hline \multirow{8}{*}{$\begin{array}{l}\text { Composition of amino } \\
\text { acid }\end{array}$} & Glycine & $32.9 \%$ \\
\hline & Proline & $13.3 \%$ \\
\hline & Alanine & $11.6 \%$ \\
\hline & Hydroxy proline & $10.2 \%$ \\
\hline & Arginine & $4.4 \%$ \\
\hline & Aspartic acid & $4.1 \%$ \\
\hline & Serine & $3.4 \%$ \\
\hline & Others & $20.1 \%$ \\
\hline \multirow{5}{*}{$\begin{array}{l}\text { Distribution of molecular } \\
\text { weight }\end{array}$} & $10,000 \sim$ & $17 \%$ \\
\hline & $3,000 \sim 10,000$ & $59 \%$ \\
\hline & $1,000 \sim 3,000$ & $21 \%$ \\
\hline & $500 \sim 1,000$ & $2 \%$ \\
\hline & $\sim 500$ & $1 \%$ \\
\hline$\overline{\mathrm{M}} \mathrm{n}$ & \multicolumn{2}{|c|}{5,200} \\
\hline$\overline{\mathrm{M} w}$ & \multicolumn{2}{|c|}{6,785} \\
\hline$\overline{\mathrm{M}} \mathrm{w} / \overline{\mathrm{M}} \mathrm{n}$ & \multicolumn{2}{|c|}{1.3048} \\
\hline
\end{tabular}<smiles>[R]c1ccc(O)c(O)c1</smiles>

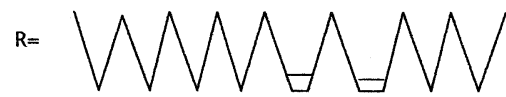

$4-\left\{9^{\prime}(\mathrm{Z}), 12^{\prime}(\mathrm{Z})\right.$-octadecadienyl $\}$ catechol

Fig. 2 Chemical structure of synthesized urushiol analog

\subsection{Preparing of samples}

\subsubsection{Modified urushi}

The ki-urushi used in this study was extracted in China. The suke-urushi samples. were prepared by adding 0, 4, 8 and $12 \mathrm{wt} \%$ protein hydrolyzate into $\mathrm{ki-}$ urushi. All these samples were processed with threeroll mill ${ }^{3)}$ and each contained about $5 \mathrm{wt} \%$ of water. These films were dried under $20^{\circ} \mathrm{C} / 70 \% \mathrm{RH}$ and $10^{\circ} \mathrm{C} / 50$ $\% \mathrm{RH}$. The former corresponds to the drying condition in muro and the latter is the typical condition in daytime of winter in Japan.

2.2.2 Artificial urushi

In the artificial urushi, as the third component (polysaccharide and glycoprotein in urushi) which emulsifies $p$-laccase and urushiol analog, starch-urea phosphate was used in our previous report ${ }^{6)}$. We proved that the best addition ratio is amount of $10 \mathrm{wt} \%$ that is equal to polysaccharide and glycoprotein in urushi. So, protein hydrolyzate was added in the amount of $10 \mathrm{wt} \%$ for $4^{-}\left\{9^{\prime}(z), 12^{\prime}(z)\right.$-Octadecadienyl $\}$ catechol. P-laccase was added into the mixture. Mixing was continued under cool air blow until the water content reached about $10 \mathrm{wt} \%$. Enzyme activity for $1 \mathrm{~g}$ of $4-\left\{9^{\prime}(z), 12\right.$ ' (z)-Octadecadienyl $\}$ catechol is 122,000 unit, this unit value is appropriate according to the findings of our previous report ${ }^{5,6)}$. P-laccase of $154 \mu 1$ was added into 1 $\mathrm{g}$ of $4^{-}\left\{9^{\prime}(z), 12^{\prime}(z)-\right.$ Octadecadienyl $\}$ catechol. Starchurea phosphate was prepared to compare with protein hydrolyzate. These films were dried under 50, 60 and 70 $\% \mathrm{RH}$ at $20^{\circ} \mathrm{C}$. Incidentally, the protein hydrolyzate was prepared in $50 \mathrm{wt} \%$ aqueous solution.

\subsection{Measurements}

\subsubsection{Drying time}

The samples were coated on glass plates $(2.5 \times 35 \mathrm{~cm})$ by using a film applicator (slit thickness $37.5 \mu \mathrm{m}$ ). A RCI type drying time recorder was installed in the thermohygrostat which was set up for the prescribed drying conditions. Drying time was determined by reading the time when a scratch of needle had completely disappeared on the coated samples. The drying conditions were the same as those in 2.2.

\subsubsection{Dynamic viscoelasticity}

The samples were coated on glass plates $(7 \times 15 \mathrm{~cm})$ with an applicator (slit thickness $50 \mu \mathrm{m}$ ), and were hardened under the prescribed conditions. The free films $(3 \times 28 \mathrm{~mm}, 20 \pm 5 \mu \mathrm{m})$ were stripped from glass plate, and the temperature dependence of the dynamic viscoelasticity was measured with a Reoviron DDV-II -EP (Orientec Co. Ltd.). Measurements were carried out under temperatures from $20^{\circ} \mathrm{C}$ to $200^{\circ} \mathrm{C}$, frequency $3.5 \mathrm{~Hz}$ and the rate of temperature rise $1^{\circ} \mathrm{C} / \mathrm{min}$. The drying conditions were the same as those in 2.2 .

\subsubsection{Viscosity}

The viscosity of the modified urushi was measured at $20^{\circ} \mathrm{C}$ with cone-plate viscometer (Tokimec Co. Ltd.).

\section{Results and Discussion}

\subsection{Application of modified urushi}

The drying rate of suke-urushi was improved greatly by the addition of the protein hydrolyzate. The results are shown in Fig. 3. Generally, it takes 5 to 10 hours for usual suke-urushi to dry up under $20^{\circ} \mathrm{C} / 70 \% \mathrm{RH}$, but the suke-urushi containing the protein hydrolyzate could dry in a few hours under the same condition.

Based on this result, viscoelasticity of the film was 


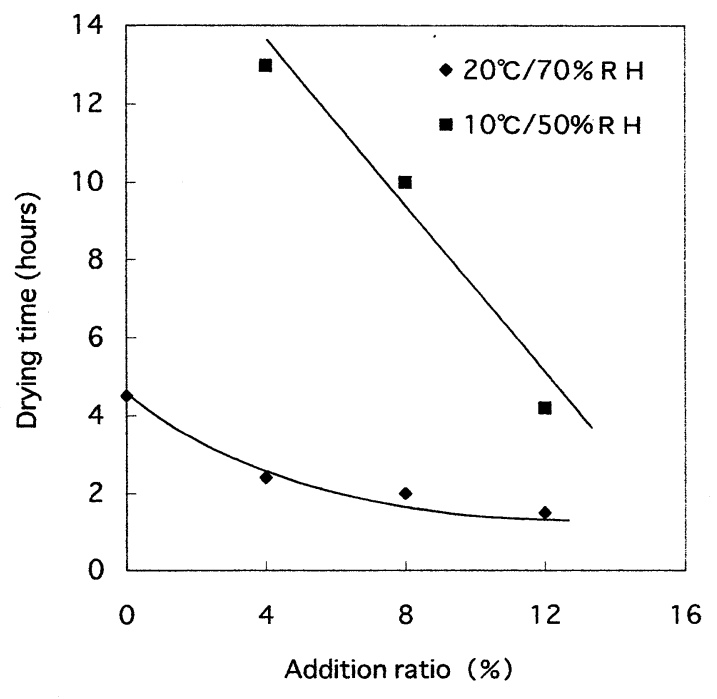

Fig. 3 Relation between addition ratio of protein hydrolyzate and drying time of suke-urushi

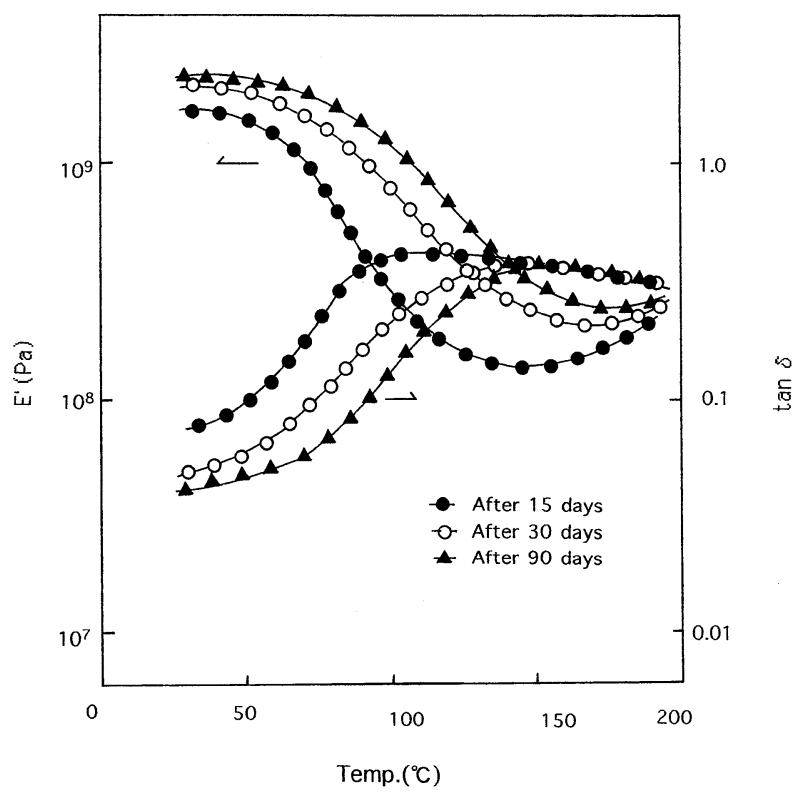

Fig. 4 Changes of dynamic viscoelasticity of suke-urushi including protein hydrolyzate dried under $10^{\circ} \mathrm{C} / 50$ $\%$ RH with time

observed. We will show the changes of dynamic viscoelasticity of suke-urushi film adding protein hydrolyzate in the amount of $8 \mathrm{wt} \%$ and drying under $10^{\circ} \mathrm{C} / 50$ $\% \mathrm{RH}$ in Fig. 4. E' of the film increased with the aging time, and the tendency was remarkable in high temperature region. The maximum value of $\tan \delta$ declined and the temperature of $\tan \delta_{\max }$ increased with time. After 15 days, $\mathrm{E}^{\prime}$ at room temperature exceeded $10^{9} \mathrm{~Pa}$, tan $\delta$ curve was broad, and the temperature of $\tan \delta_{\max }$ was approximately $100^{\circ} \mathrm{C}$. After 90 days, the temperature of $\tan \delta_{\max }$ rose to around $150^{\circ} \mathrm{C}$. The results demonstrated that the cross-linking reaction by the oxidative polymerization of urushiol side-chain was very slow

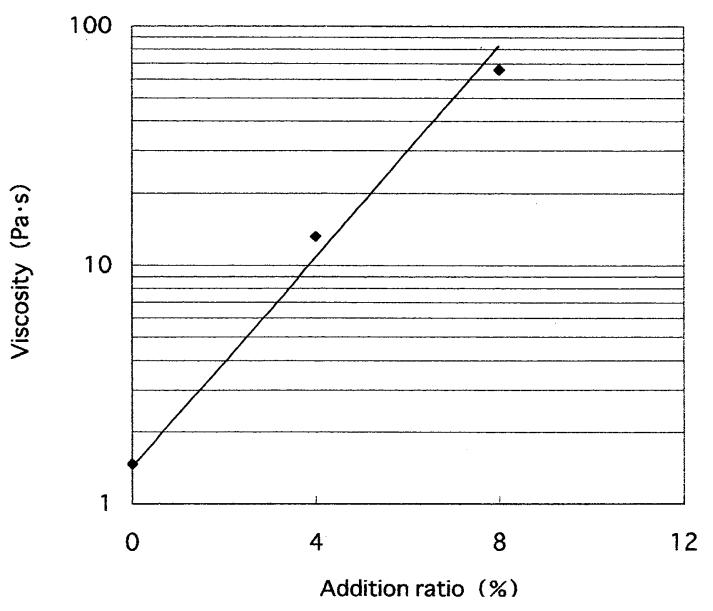

Fig. 5 Relation between addition ratio of protein hydrolyzate and viscosity of suke-urushi

and it took a long time until the cross-linking density becomes enough ${ }^{14)}$. The suke-urushi film containing the protein hydrolyzate maintained sufficient characteristics as an urushi film when it cured at low temperature under low humidity.

We consider the practical use of urushi from the relationship between viscosity and drying time. The relationship between the amount of the protein hydrolyzate added and viscosity of the suke-urushi is shown in Fig. 5. The viscosity increased monotonously with adding more protein hydrolyzate. The viscosity of sukeurushi containing $12 \mathrm{wt} \%$ protein hydrolyzate was over $100 \mathrm{~Pa} \cdot \mathrm{s}$ and exceeded the measuring range of the cone - plate viscometer. When urushi is exposed to air, its color changes instantly from brown to red-brown, which means urushiol turned easily to urushiol-quinone by action of laccase. Consequently when the suke-urushi containing the protein hydrolyzate was processed by three-roll mill, urushiol turned to urushiol-quinone as a matter of course ${ }^{1,2,3)}$. Urushiol-quinone reacted with protein hydrolyzate and the viscosity of suke-urushi containing the protein hydrolyzate increased. When we measured the viscosity of urushi generally used, it was 1.6 to $80 \mathrm{~Pa} \cdot \mathrm{s}^{15)}$. If the viscosity is beyond this value, it is impossible to paint with brush. Therefore we consider that the upper limit of addition ratio of the protein hydrolyzate is about $8 \mathrm{wt} \%$ from Fig.5. Under the drying condition of $10^{\circ} \mathrm{C} / 50 \% \mathrm{RH}$, it took 10 hours to dry up the suke-urushi contained $8 \mathrm{wt} \%$ of the protein hydrolyzate. Then it was possible to recoat on the next day.

The protein hydrolyzate having the average molecular weight of about 6,000 used in this report was found to be most suitable, because modified urushi containing it had drying at low temperature under low humidity and was possible to paint with brush. The increase of 
Table 2 Drying time of artificial urushi

\begin{tabular}{|c|c|c|c|}
\hline & $20^{\circ} \mathrm{C} 50 \% \mathrm{RH}$ & $20^{\circ} \mathrm{C} 60 \% \mathrm{RH}$ & $20^{\circ} \mathrm{C} 70 \% \mathrm{RH}$ \\
\hline Adding protein hydrolyzate* & 17.0 hours & 11.0 hours & 8.5 hours \\
\hline Adding starch-urea phosphate** & $\times^{* * *}$ & 60 hours & 35 hours \\
\hline
\end{tabular}

*Adding protein hydrolyzate in the amount of $10 \mathrm{wt} \%$

**Adding starch-urea phosphate in the amount of $10 \mathrm{wt} \%$

*** Represents no drying

molecular weight of protein hydrolyzate accelerates drying rate but it is not practical because of the increase of viscosity. When higher molecular weight protein hydrolyzate (average molecular weight of about 10,000) was used, the drying rate was much improved, but it thickened and it was impossible to paint with brush. In case of protein hydrolyzate of low molecular weight (average molecular weight of about 1,000 ) by further hydrolysis, drying rate could be improved a little. Modified urushi must be dried at low temperature under low humidity and be possible to paint with brush.

Furthermore, it is found that the suke-urushi to which the protein hydrolyzate is added not only has an improved drying rate, but also causes much less rash (dermatitis) because the reaction with protein of the skin is controlled by the bonding of urushiol with amino groups of the protein hydrolyzate.

\subsection{Application of artificial urushi}

The results on drying time for artificial urushi are summarized in Table 2. In our previous report, the artificial urushi was developed without any ingredients of urushic). An urushiol analog was synthesized and after adding of $p$-laccase to it, the water in oil emulsion was formed by adding starch urea phosphate. Although the drying rate of this artificial urushi at $20^{\circ} \mathrm{C} / 80 \% \mathrm{RH}$ was satisfactory, it became extremely unfavorable with the drop in humidity. The same tendency was observed in this experiment. When we added starch urea phosphate, the artificial urushi did not dry at $20^{\circ} \mathrm{C} / 50 \% \mathrm{RH}$. However, when protein hydrolyzate was added to the artificial urushi, it dried in 17 hours even at $20^{\circ} \mathrm{C} / 50 \%$ $\mathrm{RH}$. Accordingly, utilizing of protein hydrolyzate made it possible to dry the artificial urushi under low humidity.

Next, the viscoelasticity of artificial urushi containing protein hydrolyzate will be reported. Almost the same changes as urushi film were observed with the aging time. In order to confirm the effect of protein hydrolyzate, we will show the dynamic viscoelasticity of the artificial urushi films, one using protein hydrolyzate and the other using starch-urea phosphate drying under $20^{\circ} \mathrm{C} / 60 \% \mathrm{RH}$ after 3 months in Fig. 6. The artificial urushi film using protein hydrolyzate gives similar

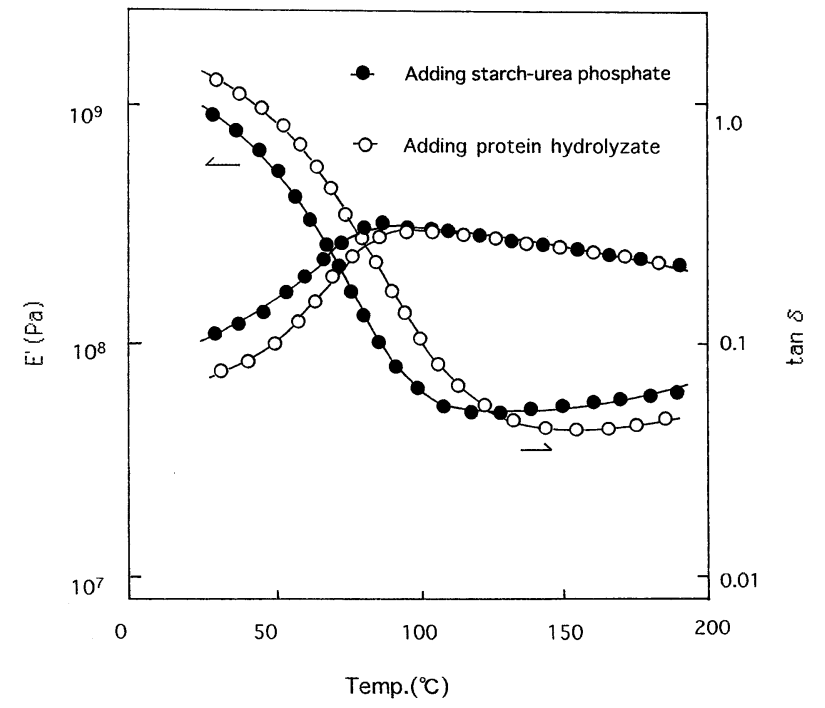

Fig. 6 Dynamic viscoelasticity of artificial urushi dried under $20^{\circ} \mathrm{C} / 60 \% \mathrm{RH}$ after 3 months

results of urushi film. E' at room temperature exceeds $10^{9} \mathrm{~Pa}$ and the temperature of $\tan \delta_{\max }$ has the value of approximately $100^{\circ} \mathrm{C}$. On the other hand, the cure of the artificial urushi film using starch-urea phosphate instead of protein hydrolyzate is found to be insufficient because of low E' and low temperature of $\tan \delta_{\max }$. Therefore, protein hydrolyzate is thought to contribute somewhat to the cure of the artificial urushi film and makes it possible to dry under low humidity.

As mentioned above, we could develop an artificial urushi that dried up even under low humidity utilizing the protein hydrolyzate. This means that a humid dry chamber is no more necessary, and the practical use of urushi analog, environmental-friendly paint, is forwarded greatly.

\subsection{Estimated reaction mechanism}

The result of this experiment suggests that some kinds of reaction occur between urushiol or synthesized urushiol analog and the protein hydrolyzate. It can be estimated whether glycoprotein reacts with urushiol by investigating the change of composition of glycoprotein before and after processing of urushi ${ }^{7)}$.

As mentioned before, the contact dermatitis is generated by the reaction between urushiol and protein of the skin $^{16)}$. Mason proposed a mechanism on the reaction between pentadecyl catechol, urushiol analog, and pro- 
色材，76〔4〕(2003)

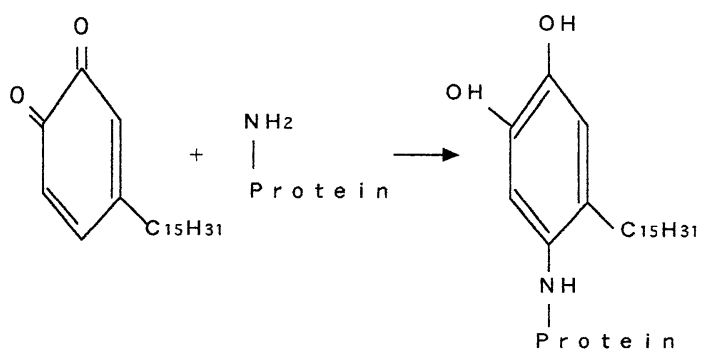

Fig. 7 Reaction between urushiol analog and protein of the skin

tein of the skin as shown in Fig. $\mathbf{7}^{9,10)}$. We considered that a similar reaction must be occurring in our system containing the protein hydrolyzate. Urushiol or urushiol analog turns to quinone by the work of laccase and it reacts with amino group of the protein hydrolyzate. This intermediate product of urushiol or urushiol analog and protein hydrolyzate forms a core and after that conventional reactions proceed successively promoted by laccase between this core and urushiol or urushiol analog. As a result a polymer of urushiol or urushiol analog is finally formed.

\section{Conclusions}

The protein hydrolyzate improved greatly the drying rate of suke-urushi and artificial urushi. Adding the protein hydrolyzate made suke-urushi dry at low temperature under low humidity in comparison with the traditional drying process. Therefore it is expected that the application field of urushi can expand. Utilizing protein hydrolyzate as the third component made artifi-

cial urushi dry under low humidity. Therefore the practical use of this environmental-friendly paint was forwarded greatly.

\title{
References
}

1) Kumanotani, J. : Tosokogaku, 26 (1991), 251

2) Kenjo, T.: Shikizai, 46 (1973), 420

3) Oyabu, H., Asami, T., Yamamoto, O. and Tajima, H. : Shikizai, 65 (1992), 349

4) Oyabu, H., Asami, T., Terada, M., Aso, Y. and Oda, Y. : Shikizai, 65 (1992), 469

5) Terada, M., Oyabu, H., Aso, Y.: Shikizai, 67 (1994), 681

6) Oyabu, H., Terada, M., Aso, Y. and Oda, Y. : Shikizai, 68 (1995), 729

7) Adachi, K., Oyabu, H. and Oda, Y. : J. Agric. Chem. Soc. Koen Yoshi, (1991) P.150

8) Aso, Y., Goto, K., Asano, H., Adachi, K. and Oda, Y. : J. Agric. Chem. Soc. Koen Yoshi, (1991) P.49

9) Mason, H. S. and Lada, A. : J. Invest. Dermatol., 22, 457 (1954)

10) Mason, H. S. : Nature, 175 (1955), 771

11) Pupuis, G. : Brit. J. Dermatol., 101 (1979), 617

12) Oda, Y., Kato, H., Isoda, Y., Takahashi, N., Yamamoto, T., Takada, Y. and Kudo, S. : Agri. Biol. Chem., 53 (1989), 2053

13) Terada, A. and Oda, Y. : Shikizai Koen Yoshi, (1986) P.34

14) Oyabu, H. : Orientic Review, 10 (1989), 4

15) Asami, T., Oyabu, H. and Yamauchi, A. : Shikizai, 58 (1985), 129

16) Kawai, K. : Nippikyo J., 38 (1997), 77

\section{蛋白質加水分解物を用いた漆㧍よび人工漆の乾燥性の改善}

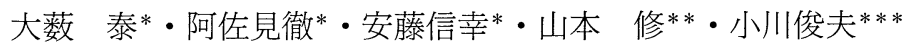 \\ *京都市工業試験場 京都市下京区中堂寺南町 17 （广 600-8813） \\ ***株式会社山本化学製品所 大阪市淀川区田川 3 丁目 9-45 （† 532-0027） \\ ***金沢工業大学 石川県野々市町扇が丘 7-1 （テ921-8821）
}

\footnotetext{
要 旨

漆抢よび人工漆の乾燥性の改善のため, 硬蛋白質を酵素で加水分解して得られた蛋白質加水分解物を利用した。

漆の低温低湿下での乾燥性を調べるため，生漆に蛋白質加水分解物を添加し，最も一般的な漆である透漆を作成した。この透 け漆は $10^{\circ} \mathrm{C} / 50 \% \mathrm{RH}$ でも乾燥し，漆の乾燥性としては画期的であった。

一方，漆をモデルとした酵素反応による塗料，つまり人工漆を開発するために，第 3 成分として蛋白質加水分解物を使用し

て, 合成したウルシオール類似物に酵素ラッカーゼを作用させた。酵素は木材不朽菌であるヒイロタケの培養液より生産し, ウ ルシオール類似物は合成した $4-\left\{9^{\prime}(z), 12^{\prime}(z)\right.$-オクタデカジエニル $\}$ カテコールを使用した。この人工漆は $20^{\circ} \mathrm{C} / 50 \% \mathrm{RH}$ の低 湿でさえも乾燥した。

さらに蛋白質加水分解物を含んだ透漆および人工漆の動的粘弾性は一般的な漆のように $\tan \delta$ 曲線はブロードで $\tan \delta_{\max }$ の温 度は高かった。

以上の結果から漆の利用拡大と漆をモデルとした環境に優しい塗料の害用化に向けて大きく前進した。
} 